\title{
PENGARUH RASIO KEUANGAN PERBANKAN TERHADAP KINERJA KEUANGAN PERBANKAN DI BEI TAHUN 2011-2016
}

\author{
Eric Arissaputra Teja \\ Fakultas Ekonomi Magister Akuntansi, Universitas Tarumanagara Jakarta \\ Email: eric.arissaputra09@gmail.com
}

\begin{abstract}
The purpose of this research is to obtain empirical evidence of capital adequacy, liquidity, operational efficiency and asset quality on financial performance.The number of sample used in this study is 126 samples from 21 banking companies from 2011-2016 period. The samples of this study are conventional general banking companies listed in Indonesia Stock Exchange from 2011-2016 period. The result of the research shows that capital adequacy and liquidity have a positive effect on financial performance while operational efficiency and asset quality have a negative effect on financial performance.
\end{abstract}

Keywords : Banking Financial Ratio, Banking Financial Performance, Capital Adequacy, Liquidity, Operational Efficiency

\section{ABSTRAK}

Penelitian ini bertujuan untuk mendapatkan bukti empiris mengenai kecukupan modal, likuiditas, efisiensi operasional dan kualitas aset terhadap kinerja keuangan. Jumlah sampel yang digunakan dalam penelitian ini adalah 126 sampel dari 21 perusahaan perbankan tahun 2011-2016. Sampel penelitian ini menggunakan perusahaan perbankan umum konvensional yang terdaftar di Bursa Efek Indonesia tahun 2011-2016. Hasil penelitian menunjukkan kecukupan modal dan likuiditas berpengaruh positif terhadap kinerja keuangan sedangkan efisiensi operasional dan kualitas asset berpengaruh negatif terhadap kinerja keuangan.

Kata Kunci: modal, likuiditas, efisiensi, kualitas aset, kinerja keuangan

\section{PENDAHULUAN}

\section{Latar Belakang}

Bank merupakan lembaga perantara keuangan dari pihak-pihak pemilik dana dengan pihak-pihak yang membutuhkan dana. Selain itu, kegiatan bank tidak hanya semata-mata untuk kebutuhan transaksi, tetapi juga untuk kebutuhan investasi. Dengan demikian, penilaian terhadap kinerja keuangan perbankan harus senantiasa dilakukan agar dapat mengetahui tingkat kesehatannya serta menentukan arah kebijakan strategi bank dimasa yang akan datang. Pengukuran kinerja menggunakan aspek keuangan lebih sering digunakan karena ada standar pembanding yang potensial, baik berupa laporan keuangan dimasa lalu maupun laporan keuangan antar perusahaan sejenis (Hansen \& Mowen, 1997).

Profitabilitas merupakan salah satu indikator yang dapat digunakan untuk mengukur kinerja keuangan suatu bank. Dalam proses bisnis, suatu perusahaan harus menghasilkan keuntungan agar dapat mempertahankan keberadaan perusahaan dan mencapai keberlanjutan usaha dalam jangka panjang serta menarik minat investor untuk berinvestasi dalam perusahaan tersebut. Kinerja perbankan sendiri dipengaruhi oleh dua faktor penentu, yakni faktor internal dan eksternal. Faktor internal merupakan faktor yang dipengaruhi oleh kebijakan dan keputusan manajemen dalam menjalankan perusahaan. Sedangkan faktor eksternal merupakan faktor yang tidak dapat dikendalikan oleh manajemen seperti keadaan ekonomi makro suatu negara serta karakteristik industri (Shahchera, 2012).

Penelitian mengenai pengaruh kecukupan modal, likuiditas, efisiensi operasional dan kualitas aset terhadap kinerja keuangan pada perusahaan perbankan yang terdaftar di Bursa Efek Indonesia telah banyak dilakukan. Namun, hasil penelitian-penelitian terdahulu menunjukkan hasil yang berbeda-beda serta pergerakan yang rasio keuangan 
yang fluktuatif menjadi dasar peneliti untuk mengkaji lebih mendalam. Oleh karena itu, dilakukanlah analisis untuk menilai pengaruh rasio keuangan perbankan terhadap kinerja keuangan di sektor perbankan yang terdaftar di bursa efek indonesia tahun 2011-2016.

\section{Kajian Teori}

Teori keagenan oleh Jensen dan Meckling (1976) menyatakan antara pemilik (principal) dan manajer (agent) mempunyai kepentingan yang berbeda. Adanya berbagai kepentingan ini, masing-masing pihak berusaha untuk memperbesar keuntungan bagi dirinya sendiri. Salah satu perbedaan kepentingan antara pemegang saham dan manajer antara lain maksimalisasi manfaat (utility) pemegang saham dengan kendala insentif yang diterima manajer. Hal ini menyebabkan konflik antara pemilik dan pemegang saham.

Signaling Theory mengisyaratkan bahwa kinerja keuangan yang tinggi merupakan sinyal bagi investor untuk mendapatkan return yang tinggi atas investasinya (Leland dan Pyle, 1977). Dengan demikian, adanya sinyal-sinyal ini diharapkan kinerja keuangan perusahaan dapat memberikan signal positif. Sinyal ini akan memberikan dampak kepada para pelaku bursa untuk melakukan investasi melalui pembelian saham perusahaan. Semakin banyak para pelaku bursa yang melakukan investasi pada perusahaan akan mendorong transaksi volume perdagangan sahamnya meningkat. Hal ini akan berdampak pada peningkatan harga pasar saham perusahaan atau peningkatan kinerja perusahaan.

Bank adalah sebuah badan usaha yang menghimpun dana dari masyarakat dalam bentuk simpanan dan menyalurkannya kepada masyarakat dalam bentuk kredit dan atau bentuk-bentuk lain dengan tujuan untuk meningkatkan taraf hidup orang banyak (Undang-undang RI nomor 10 Tahun 1998 tentang Perbankan pasal 1 ayat 2).

Kinerja keuangan. Menurut Kimathi et al. (2015), kinerja keuangan didefinisikan sebagai berikut: "A financial performance measure provides a valuable tool to stakeholders to evaluate the past financial performance and the current position of a firm." Selain itu, Naser dan Mokhtar (2004) mengemukakan "A firm's high performance reflects its effectiveness and efficiency in the management of its resources for operational, investment and financing activities." Berdasarkan pengertian di atas, maka dapat disimpulkan bahwa kinerja keuangan adalah alat pengukuran bagi pemangku kepentingan dalam melakukan evaluasi kinerja baik tahun sebelumnya ataupun tahun berjalan. Profitabilitas merupakan salah satu indikator yang dapat digunakan untuk mengukur kinerja keuangan suatu bank. Menurut Menicucci dan Paolucci (2015), "Profitability refers to the ability of the business organization to maintain its profit year after year". Menurut Gitman (2003:591), "Profitability is the relationship between revenues and cost generated by using the firm's asset- both current and fixed-in productive activities". Berdasarkan pengertian diatas maka dapat disimpulkan bahwa profitabilitas adalah kemampuan perusahaan dalam menghasilkan laba dengan menggunakan sumberdaya yang ada di dalam perusahaan itu sendiri.

Kecukupan modal dapat diartikan sebagai kemampuan bank dalam menampung risiko kerugian yang kemungkinan dihadapi. Kemudian Kosmidou (2008), "Capital adequacy refers to the sufficiency of the amount of equity to absorb any shocks that the bank may experience". "Capital Adequacy Ratio (CAR) is the ratio of a bank's capital in relation to its risk weighted assets and current liabilities. It is decided by central banks and bank regulators to prevent commercial banks from taking excess leverage and becoming insolvent in the process." Dalam penelitian ini, kecukupan modal diukur menggunakan Capital Adequacy Ratio (CAR). Capital Adequacy Ratio merupakan indikator terhadap kemampuan bank untuk menutupi penurunan aktivanya sebagai akibat dari kerugian - kerugian bank yang disebabkan oleh aktiva yang berisiko. Basel Accords I (1988) merupakan dasar dari Peraturan Otoritas Jasa Keuangan Nomor 11/POJK.03/2016 
pasal 2 menyatakan bahwa bank wajib menyediakan modal minimum sebesar $8 \%$ dari aset tertimbang menurut resiko (ATMR).

Likuiditas. Menurut Shim dan Siegel (2000), “Liquidity is the company's capacity to liquidate maturing short-term debt (within one year)". Salike dan Ao (2017) mengatakan, "Liquidity is the ratio of liquid assets to liquid liabilities and is a proxy for banks' ability to repay their clients' shot-term deposits and other funds at maturity". Dengan demikian, dapat disimpulkan bahwa likuiditas merupakan kemampuan suatu bank atau suatu perusahaan untuk memenuhi kewajiban-kewajiban jangka pendeknya. Likuiditas pun diatur dalam Basel Accords II pillar 2 : Supervisory re view (2004) yang mengatakan "financial risk that for a certain period of time a given financial asset, security or commodity cannot be traded quickly enough in the market without impacting the market price". LDR ini menjadi salah satu tolak ukur likuiditas bank yang berjangka waktu agak panjang. Batas aman untuk LDR menurut Bank Indonesia adalah $80 \%$ hingga $110 \%$. Jika angka LDR suatu bank berada pada angka dibawah $80 \%$ maka dapat disimpulkan bahwa bank tersebut tidak menjalankan fungsinya dengan baik karena fungsi utama dari bank adalah sebagai intermediasi (perantara) antara pihak yang kelebihan dana dengan pihak yang kekurangan dana. Tetapi jika LDR bank mencapai lebih dari $110 \%$, berarti bank dapat dikatakan tidak menjalankan fungsinya sebagai pihak intermediasi (perantara) dengan baik karena total kredit yang diberikan bank tersebut melebihi dana yang dihimpun.

Efisiensi sebagai parameter kinerja perbankan dan merupakan salah satu penilaian tingkat kesehatan Bank. Perbankan efisien mencerminkan kemampuan meminimalkan biaya untuk memaksimalkan output. Basel Accords II pillar 1 : regulatory capital (2004) membahas mengenai efisiensi operasional dalam operational risk yang menjelaskan bahwa "the risk of loss resulting from inadequate or failed internal processes, people and systems or from external events". Purwoko dan Sudiyatno (2013) mengatakan, "Secara konseptual, bank-bank yang bekerja secara efisien akan dapat menghasilkan laba yang tinggi, karena dengan efisiensi biaya operasi tersebut akan memaksimalkan pendapatan bank." Efisiensi operasional berfungsi mengukur kinerja operasi perbankan yang umumnya fokus pada bagaimana input atau sumber daya perbankan (seperti sumber daya alam, modal, sumber daya manusia) dapat menghasilkan output yang maksimum, atau menggunakan input yang lebih sedikit untuk menghasilkan output yang sama dengan kompetitor - kompetitor usaha lainnya.

Kualitas aset merupakan tingkat kemampuan dari aktiva yang dimiliki bank baik aktiva produktif maupun aktiva non produktif untuk memberikan manfaat bagi bank. Salike dan Ao (2017) menyatakan, "The quality of bank assets depends primarily on its portfolio of loans and internal credit administration mechanisms. Poor asset quality, also known as poor loan quality and normally represented by non-performing loans or impaired loans, is an important consideration in asset management and is an indicator of potential banking profitability." Kemudian Menicucci dan Paolucci (2015) menyatakan," Asset quality refers mainly to the quality of the bank's earning assets which include its loan portfolio." Berdasarkan pernyataan di atas, maka dapat disimpulkan bahwa non-performing loan (NPL) digunakan sebagai dasar untuk mengukur kualitas aset perbankan. Non Performing Loan (NPL) menggambarkan kemampuan manajemen bank dalam mengelola kredit bermasalah. Basel Accords II pillar 1 : regulatory capital (2004) mengatakan "the risk of default on a debt that may arise from a borrower failing to make required payments." Semakin kecil NPL, semakin kecil risiko kredit yang ditanggung pihak bank. 
Kerangka pemikiran dalam penelitian ini seperti digambarkan dibawah ini:

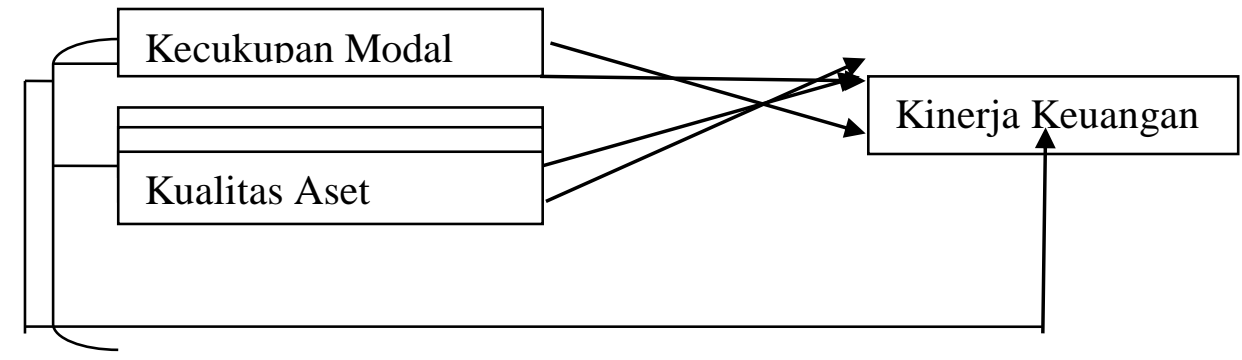

Gambar 1 Kerangka Pemikiran

Hipotesis dari model yang dibangun diatas adalah sebagai berikut;

$\mathrm{H}_{1}=$ Kecukupan modal memiliki pengaruh positif terhadap kinerja keuangan.

$\mathrm{H}_{2}=$ Likuiditas memiliki pengaruh positif terhadap kinerja keuangan.

$\mathrm{H}_{3}=$ Efisiensi operasional memiliki pengaruh negatif terhadap kinerja keuangan.

$\mathrm{H}_{4}=$ Kualitas aset memiliki pengaruh negatif terhadap kinerja keuangan.

$\mathrm{H}_{5}=$ Kecukupan modal, kualitas aset, likuiditas dan efisiensi operasional secara bersamasama memiliki pengaruh yang signifikan terhadap kinerja keuangan.

\section{METODE PENELITIAN}

Objek Penelitian. Penelitian ini difokuskan pada seluruh perusahaan perbankan yang terdaftar di Bursa Efek Indonesia pada tahun 2011-2016 yang laporannya didapat dari www.idx.co.id. Dalam penelitian ini, teknik pengambilan sampel dengan menggunakan kriteria tertentu yang ditentukan oleh peneliti untuk mendapatkan sampel sesuai dengan tujuan yang sudah ada. Berikut ini merupakan kriteria dalam pemilihan sampel :

1. Perusahaan perbankan yang terdaftar pada periode 2011-2016.

2. Perusahaan perbankan menyajikan laporan keuangan dalam website BEI selama periode 2011 -2016.

3. Perusahaan perbankan menggunakan mata uang rupiah (Rp) dalam laporan keuangannya.

4. Perbankan yang memiliki jenis Bank Umum Konvensional.

5. Perusahaan perbankan menyajikan data yang lengkap selama periode 2011-2016.

Variabel operasional dalam penelitian ini terdiri dari kecukupan modal, likuiditas, efisiensi operasional dan kualitas aset yang merupakan variabel independen, dan kinerja keuangan sebgaai variabel dependen. Kinerja keuangan dalam penelitian ini diwakili oleh Return on Asset (ROA) yang membandingkan total pendapatan dengan total asset dengan formula:

$$
\text { ROA }=\frac{\text { Net Income }}{\text { Total Asset }}
$$

Kecukupan modal dalam penelitian ini diwakili oleh Capital Adequacy Ratio.

$$
\mathrm{CAR}=\frac{\text { Modal Sendiri }}{\text { ATMR }} \times 100 \%
$$

Likuiditas dalam penelitian ini diwakiliki oleh Loan to Deposit Ratio.

$$
\mathrm{LDR}=\frac{\text { Jumiah Rredit jang Diberikan }}{\text { Total Dana Pinak Ketiga }}
$$


Efisiensi Operasional dalam penelitian ini diwakili oleh Beban Operasional Pendapatan Operasional.

$$
\mathrm{BOPO}=\frac{\text { Beban Operasional }}{\text { Pendapatan Operasional }} \times 100 \%
$$

Kualitas Aset dalam penelitian ini diwakili oleh Non Performing Loan.

$$
\text { NPL }=\frac{\text { Kredit Bermasalah }}{\text { Total Kredit }} \times 100 \%
$$

Dalam penelitian ini menggunakan uji statistik deksriptif untuk menguji sampel, uji asumsi klasik. Sedangkan uji hipotesis menggunakan uji t, uji Fdan uji koefisien determinasi ganda.

\section{HASIL DAN PEMBAHASAN}

Uji statistik deskriptif menggambarkan tentang ringkasan data penelitian seperti mean, standar deviasi, nilai minimum, nilai maksimum, sum, dan varians. Dari 126 pengambilan sampel ternyata dapat dilihat bahwa perolehan statistik deskriptif efisiensi operasional dengan nilai minimum 0,59930 , nilai maksimum 1,37940 , rata-rata sebesar 0,8326651 , dan standar deviasi sebesar 0,10514375. Kualitas aset dengan nilai minimum 0,00210, nilai maksimum 0,06860, rata-rata sebesar 0,0212000, dan standar deviasi sebesar 0,01225152. Likuiditas dengan nilai minimum 0,44240, nilai maksimum 1,13300, rata-rata sebesar 0,8315016, dan standar deviasi sebesar 0,1241800. Dan kecukupan modal memperoleh hasil dengan nilai minimum 0,10440 , nilai maksimum 0,45750 , rata-rata sebesar 0,1768246, dan standar deviasi sebesar 0,04195864.

Uji asumsi klasik. Uji normalitas yang dilakukan pada penelitian ini, tingkat signifikansi sebesar 0,058 yang berada di atas 0.05 . Hal ini menunjukkan bahwa data telah terdistribusi secara normal. Uji autokorelasi yang dilakukan pada penelitian ini, angka DW senilai 2,120. Tabel DW dengan jumlah data $(n)=126$ dan $\mathrm{k}=4$, diperoleh nilai du sebesar 1,7751 dan nilai 4 - du sebesar 2,2249 (lihat pada lampiran). Dapat disimpulkan bahwa tidak terjadi masalah autokorelasi pada model regresi karena nilai DW terletak diantara du dan (4-du), di mana 2,120 terletak diantara 1,7751 dan 2,2249.

Uji multikolinearitas pada penelitian ini menunjukkan bahwa nilai VIF untuk efisiensi operasional 1,186, nilai VIF untuk kualitas aset 1,222, nilai VIF untuk likuiditas 1,045, dan nilai VIF untuk kecukupan modal 1,030. Berdasarkan hasil di atas berarti semua variabel independen tidak terdapat VIF yang nilainya lebih dari 10 sehingga memenuhi syarat sebagai data yang baik dan bebas dari masalah multikolinearitas. Uji heteroskedastisitas dalam penelitian ini menunjukkan nilai efisiensi operasional sebesar 0,852>0,05 yang berarti variabel efisiensi operasional tidak terjadi masalah heteroskedastisitas. Nilai kualitas aset yang mempunyai nilai signifikansi sebesar 0,575 > 0,05 berarti variabel kualitas aset tidak terdapat masalah heteroskedastisitas. Nilai likuiditas sebesar 0,678>0,05 berarti likuiditas tidak terdapat masalah heteroskedastisitas. Dan nilai kecukupan modal sebesar 0,585 yang artinya variabel ini tidak terjadi masalah heteroskedastisitas karena nilainya lebih dari 0,05.

Berdasarkan hasil penelitian yang dilakukan, maka peneliti mencoba memberikan pokok- pokok temuan penelitian secara keseluruhan. Hasil Analisis regresi data panel dapat disimpulkan dengan persamaan model regresi yaitu:

$$
\mathrm{Y}=0,107-0,110 \mathrm{X}_{1}-0,042 \mathrm{X}_{2}+0,002 \mathrm{X}_{3}+0,021 \mathrm{X}_{4}+\mathrm{e}
$$

Dari persamaan diatas, nilai constant sebesar 0,107. Hal ini berarti apabila variabel struktur modal, ukuran perusahaan, dan likuiditas sama dengan nol atau 
diabaikan, maka nilai kinerja keuangan adalah sebesar 0,107. Uji t adalah uji yang digunakan untuk mengetahui pengaruh antara variabel independen dengan variabel dependen. Untuk menguji hipotesis nol ditolak atau diterima, titik tolaknya adalah bila nilai prob < atau >0,05, artinya jika nilai signifikansi dari variabel independen di bawah 0,05, maka hipotesis diterima dan sebaliknya. Uji $\mathrm{F}$ dilakukan untuk mengetahui hubungan antara variabel independen secara simultan terhadap variabel dependen. Untuk mengetahui korelasi variabel-variabel independen terhadap variabel dependen, maka dilakukan uji koefisien determinasi $\left(\mathrm{R}^{2}\right)$. Berdasarkan hasil pengolahan data, didapatkan angka $\mathrm{R}^{2}$ sebesar 0.867. Jadi, dapat disimpulkan bahwa 86,7\% varabel dependen dapat dijelaskan oleh variasi dari keempat variabel independen, sedangkan sisanya sebesar 13,3\% dapat dijelaskan oleh variabel-variabel lain diluar penelitian. Hasil uji ini dapat dilihat pada tabel dibawah ini.

\section{Tabel 1 Hasil Uji F}

ANOVAa

\begin{tabular}{|rl|r|r|r|r|r|}
\hline \multicolumn{1}{|l|}{ Model } & Sum of Squares & Df & Mean Square & F & Sig. \\
\hline \multirow{2}{*}{1} & Regression &, 017 & 4 &, 004 & 204,803 &, $000^{\mathrm{b}}$ \\
& Residual &, 003 & 121 &, 000 & & \\
& Total &, 020 & 125 & & \\
\hline
\end{tabular}

a. Dependent Variable: ROA

b. Predictors: (Constant), CAR, LDR, BOPO, NPL

Tabel 2 Hasil Uji t

Coefficients

\begin{tabular}{|c|c|c|c|c|c|c|c|c|}
\hline \multirow{2}{*}{\multicolumn{2}{|c|}{ Model }} & \multicolumn{2}{|c|}{ Unstandardized Coefficients } & \multirow{2}{*}{$\begin{array}{c}\text { Standardized } \\
\text { Coefficients } \\
\text { Beta }\end{array}$} & \multirow[t]{2}{*}{$\mathrm{T}$} & \multirow[t]{2}{*}{ Sig. } & \multicolumn{2}{|c|}{ Collinearity Statistics } \\
\hline & & $\mathrm{B}$ & Std. Error & & & & Tolerance & VIF \\
\hline \multirow{5}{*}{1} & (Constant) &, 107 &, 005 & & 23,532 &, 000 & & \\
\hline & BOPO &,- 110 & ,004 &,- 924 & $-25,999$ &, 000 &, 843 & 1,186 \\
\hline & NPL &,- 042 & 037 &,- 041 & $-1,140$ & ,256 &, 818 & 1,222 \\
\hline & LDR & ,002 &, 003 & ,022 & 649 &, 518 & ,957 & 1,045 \\
\hline & CAR & ,021 & ,010 &, 071 & 2,160 & 033 & ,971 & 1,030 \\
\hline
\end{tabular}

a. Dependent Variable: ROA

Tabel 3 Hasil UjiAdjusted $\mathbf{R}^{2}$

Model Summary ${ }^{b}$

\begin{tabular}{|l|r|r|r|r|r|}
\hline Model & \multicolumn{1}{|c|}{$\mathrm{R}$} & R Square & \multicolumn{1}{c|}{$\begin{array}{c}\text { Adjusted R } \\
\text { Square }\end{array}$} & $\begin{array}{c}\text { Std. Error of the } \\
\text { Estimate }\end{array}$ & Durbin-Watson \\
\hline 1 &, $933^{\mathrm{a}}$ &, 871 &, 867 &, 00456874 & 2,120 \\
\hline
\end{tabular}

a. Predictors: (Constant), CAR, LDR, BOPO, NPL

b. Dependent Variable: ROA 


\section{Diskusi}

Berdasarkan hasil uji t, diketahui bahwa variabel efisiensi operasional berpengaruh negatif dan signifikan terhadap kinerja keuangan, kualitas aset berpengaruh negatif dan tidak signifikan terhadap kinerja keuangan, likuiditas berpengaruh positif dan tidak signifikan terhadap kinerja keuangan, dan kecukupan modal berpengaruh positif dan signifikan terhadap kinerja keuangan. Hasil uji $\mathrm{F}$ menunjukkan bahwa variabel independen berpengaruh signifikan terhadap variabel dependen.

\section{KESIMPULAN DAN SARAN}

Berdasarkan hasil pengujian data dalam penelitian ini, efisiensi operasional memiliki pengaruh negatif signifikan terhadap kinerja keuangan. Kecukupan modal memiliki pengaruh positif signifikan terhadap kinerja keuangan. Likuiditas memiliki pengaruh positif tidak signifikan terhadap kinerja keuangan dan kualitas aset memiliki pengaruh negatif tidak signifikan terhadap kinerja keuangan. Kemudian berdasarkan hasil uji F menunjukkan model regresi linear berganda tahun 2011-2016 merupakan persamaan yang layak dengan nilai signifikansi kurang dari 0,05.

Keterbatasan dari penelitian ini antara lain:

1. Rentang waktu periode pengamatan pada laporan keuangan perusahaan perbankan di Bursa Efek Indonesia hanya meliputi tahun 2011-2016.

2. Hanya melibatkan sektor perbankan umum yang terdaftar di BEI.

3. Di sisi lain, penelitian ini hanya menggunakan empat variabel independen untuk diteliti sebagai variabel yang mempengaruhi kinerja keuangan.

Berdasarkan hasil dan keterbatasan di atas, maka saran yang dapat diberikan untuk penelitian selanjutnya, antara lain:

1. Menggunakan periode penelitian yang rentang waktunya lebih lama dan dengan jumlah sampel yang lebih banyak.

2. Penelitian terhadap kinerja keuangan tidak hanya berfokus pada faktor fundamental perusahaan tetapi dari segi faktor eksternal perusahaan pun dapat berpengaruh, seperti inflasi dan tingkat suku bunga.

\section{REFERENSI}

Basel Accords I (1988), diakses dari https://en.wikipedia.org.

Basel Accords II (2004), diakses dari https://en.wikipedia.org.

Bougatef,K. (2015). Determinants of bank profitability in Tunisia: does corruption matter. Journal of Money Laundering Control, 20 (1), 70-78.

Caturini, R. (2016, Aug 08). Memagari bank dengan Basel Accord.diakses dari http://lipsus.kontan.co.id.

Ghozali, I. (2016). Aplikasi Analisis Multivariate dengan Program IBM SPSS 23 (Ed 8.). Semarang: Badan Penerbit Universitas Diponegoro.

Gitman, Lawrence, J. (2003). Principles of Managerial Finance (17th ed.). Massachusetts: Addison-Wesley Publishing Company

Hansen, D. R., Mowen, M. M. (1997). Akuntansi Manajemen. Jakarta: Penerbit Erlangga.

Hassan, M.K.,\& Bashir, A. M. (2005), Determinants of Islamic banking profitability, Paper presented at the Economic Research Forum (ERF) 10th Annual Conference, Marrakech, 16-18 Desember.

Jensen, M. C., \& Meckling, W. H. (1976). Theory of The Firm: Managerial Behavior, Agency Cost, and Ownership Structure, Jurnal of Financial Economics, 3 (4), 305-360. 
DI BEI TAHUN 2011-2016

Jha, S., \& Hui, X. (2012). A comparison of financial performance of commercial banks: A case study of Nepal. African Journal of Business Management, 6(25).

Joel. G. S \& Jae, K. S. (2000). Kamus Istilah Akuntansi. Jakarta: Gahlia Indonesia

Kawshala. H.,\& Panditharathna. K. (2017). The Factors Effecting on Bank Profitability. International Journal of Scientific and Research Publications, 7(2).

Kimathi, M. K., Galo, M. N., \& Melissa, A. G. (2015). Effect of Leverage on Performance of Non-financial Firms Listed at the Nairobi Securities Exchange. Journal of Finance and Accounting, 3(5), 132-139.

Kosmidou, K. (2008). The determinants of bank's profits in Greece during the period of EU financial integration. Managerial Finance, 34(3),146-159.

Laporan Perekonomian Indonesia 2016, diakses dari http://www.bi.go.id.

Latumeirissa, Julius R. (2012). Bank dan Lembaga Keuangan Lain. Jakarta: Salemba Empat.

Leland, E.,\& Pyle, D.(1977). Informational Asymmetries, Financial Structure, and Financial Intermediation. The Journal of Finance, 371-387.

Lukitasari, Y. P., \& Kartika, A. (2014). Faktor-Faktor Yang Mempengaruhi Kinerja Keuangan Pada Sektor Perbankan Yang Terdaftar Di Bursa Efek Indonesia. Dinamika Akuntansi, Keuangan dan Perbankan, 3 (2), 166 - 176.

Menicucci, E., \& Paolucci,G.(2015). The determinants of bank profitability: empirical evidence from European banking sector. Journal of Financial Reporting and Accounting, 14 (1), 86-115.

Naser, K., \& Mokhtar, M. (2004). Determinants of Corporate Performance of Malaysian Companies. Fourth Asia Pacific Interdisciplinary Research in Accounting Conference, Singapore

Pasaribu, R. B. F.,Kowanda, D., \& Paramitha, G. N. P. (2015). Profitabilitas Bank Di Indonesia Dengan Metode Risk Based Bank Rating Pada Emiten Perbankan di Bursa Efek Indonesia. Jurnal Riset Akuntasi Dan Keuangan Fakultas Bisnis Universitas Kristen Duta Wacana Yogyakarta, 11 (1), 15-30.

Peraturan Otoritas Jasa Keuangan Nomor 11 /POJK.03/2016 Tentang Kewajiban Penyediaan Modal Minimum Bank Umum. Diakses dari www.ojk.go.id.

Priyatno, D. (2010). Teknik Mudah dan Cepat Melakukan Analisis Data Penelitian dengan SPSS dan Tanya Jawab Ujian Pendadaran. Gaya Media, Yogyakarta.

Purwoko, D., \& Sudiyatno, B. (2013). Faktor-Faktor Yang Mempengaruhi Kinerja Bank (Studi Empirik Pada Industri Perbankan Di Bursa Efek Indonesia). Jurnal Bisnis dan Ekonomi (JBE), 20 (1), 25 - 39.

Ross, S.A.(1977). The Determination of Finacial Structure:The Incentive Signalling Approach. Journal of Economics, Spring, 8, 23-40.

Salike, N.,\& Ao, B. (2017). Determinants of bank's profitability: role of poor asset quality in Asia. China Finance Review International.

Samad, A .(2015). Determinants Bank Profitability: Empirical Evidence from Bangladesh Commercial Banks. International Journal of Financial Research, 6 (3).

Schiniotakis, N.I. (2012). Profitability factors and efficiency of Greek Banks. Euro Med Journal of Business, 7(2), 185-200.

Shahchera, M. (2012). The Impact of Liquidity Asset on Iranian Bank Profitability, International Conference on Management, Behavioral Sciences and Economics Issues (ICMBSE'2012) Penang, Malaysia 7(1), 131-135.

Sudiyatno, B. (2010). Analisis Pengaruh Dana Pihak Ketiga, BOPO, CAR dan LDR Terhadap Kinerja Keuangan Pada Sektor Perbankan Yang Go Public Di Bursa Efek Indonesia (BEI) (Periode 2005-2008). Dinamika Keuangan dan Perbankan, 125-137. 
Tan, Y., Floros, C., \& Anchor, J. (2016). The profitability of Chinese banks : impacts of risk, competition and efficiency. Review of Accounting and Finance, 16 (1),86105.

Undang-undang RI nomor 10 Tahun 1998 tentang Perbankan. Diakses dari www.hukumonline.com.

Widarjono, A. (2009). Ekonometrika Pengantar dan Aplikasinya (Ed 3.). Ekonisia. Yogyakarta.

www.idx.co.id

Www.ojk.go.id

www.investopedia.com

http://iaiglobal.or.id 